\title{
Preparing students for pharmacy practice using critical thinking and reflection
}

\author{
Kimberly B. Garza ${ }^{1}$, Channing R. Ford ${ }^{2}$ (D) Lindsey E. Moseley ${ }^{1}(\mathbb{D})$ Bradley M. Wright $^{1}(\mathbb{D})$ \\ ${ }^{1}$ Auburn University Harrison School of Pharmacy, Auburn University, Alabama, United States \\ 2 Jacksonville State University, Jacksonville, Alabama, United States
}

\author{
Keywords \\ Critical thinking \\ Patient case \\ Reflection \\ United States healthcare system
}

\section{Correspondence}

Kimberly B. Garza

Department of Health Outcomes

Research and Policy

Auburn University Harrison

School of Pharmacy

Associate Professor of Health

Outcomes Research and Policy

Auburn University Harrison

School of Pharmacy

4306B Walker Building

Auburn University, Alabama

United States

KBL0005@auburn.edu

\begin{abstract}
Background: Social, behavioural, and administrative sciences are among the Accreditation Council of Pharmacy Education (ACPE) mandated foundational knowledge requirements for pharmacy school curricula. However, they are often taught in isolation, whereby students lose sight of their meaning and significance in the Pharmacists' Patient Care Process (PPCP). Objective: The objective was to assess performance and critical thinking skills and explore student perceptions of a Longitudinal Patient Case assignment that integrates knowledge from multiple domains into a learning experience exploring how patients and pharmacists navigate the complexities of the US healthcare system. Methods: Student pharmacists developed their case throughout the term by incorporating course concepts, then submitted a narrated PowerPoint presentation. Quantitative data sources included overall scores, scores for each domain, midterm and final examination scores, and final course grades, analysed using descriptive statistics and Pearson's correlation. Student reflections encouraged self-discovery and professional identity development and served as the qualitative data source. Thematic analysis occurred through a multi-phase approach. Results: All first-year student pharmacists $(n=153)$ participated. Scores on the narrated PowerPoint were significantly correlated with midterm and final exams and were moderately correlated with overall course grades. Themes that evolved from students' selfreflections focused on project execution and learning/knowledge. Conclusions: Synthesising and applying content across a course in this manner enables students to make connections, think critically, and be creative.
\end{abstract}

\section{Introduction}

Social, behavioural, and administrative sciences are among the Accreditation Council of Pharmacy Education (ACPE) mandated foundational knowledge requirements for pharmacy school curricula (Accreditation Council for Pharmacy Education, 2015). However, they are often taught in isolation, whereby students lose sight of their meaning and significance in the Pharmacists' Patient Care Process (PPCP) (Joint Commission of Pharmacy Practitioners, 2014). This manuscript describes the development of a Longitudinal Patient Case (LPC) assignment that integrates knowledge from multiple domains into a learning experience exploring how patients and pharmacists navigate the complexities of the United States (US) healthcare system.
Engaging the learners in the health professions requires innovative instructional and assessment strategies that use multiple approaches. As accreditation standards encompass a more holistic view of the learner to include behaviours and attitudes, the focus is shifting to learning experiences that are innovative and student-centred, striving to create critical thinkers capable of caring for complex patients in an evolving healthcare environment. Accordingly, developing learning experiences using a cognitive constructivist approach provides the foundational framework necessary to produce self-directed learners. Cognitive constructivism posits that knowledge is actively constructed through authentic experiences, and existing knowledge is reshaped with every new experience (Piaget, 1950; Piaget \& Cook, 1952). When teachers create authentic experiences to help students 
'construct' their own learning, self-directed learning occurs as a result. These are students who show initiative when identifying and setting their own goals and consistently pursue new learning opportunities and skill development (Nerali et al., 2016). The inclusion of problem-based or project-based learning, like the assignment evaluated in this study, can nurture this development, as self-directed learning is a key component of these learning approaches (Vande Wiele et al., 2017). Further, approaches such as the one proposed by Perksy and the authors (2019), which demonstrates a 4-step cycle (generation, conceptualisation, optimisation, and implementation), can be utilised to help develop critical thinking in learners.

Scholars have found that students are more receptive to feedback provided by their peers and are more likely to act on that feedback (Svinicki \& McKeachie, 2014). Accordingly, peer review is a useful addition to assignments that require the development of a patient case. By providing feedback to a peer, students also begin preparing for the process of providing feedback to others on the healthcare team when in practice. This process can also increase a student's ability to critically evaluate their work more objectively, resulting in a better understanding of what constitutes quality work and supporting the student in practising the continuous quality improvement process (Svinicki \& McKeachie, 2014). When done well, the act of giving and receiving peer feedback may also strengthen a student's critical thinking skills, as it requires the student to analyse and critically evaluate the work of another.

To adequately evaluate student learning outcomes in projects that incorporate critical thinking and selfdirected learning, the utilisation of a well-defined rubric is essential. Bubb asserts that students will be more successful in achieving learning goals within highstakes assignments if a grading rubric is provided; this inclusion reduces student confusion and increases students' abilities to determine instructor expectations (2012).

\section{Learning experience design}

In 2017, the Auburn University Harrison School of Pharmacy implemented what is now known as the Practice Ready Curriculum, which focuses on student learning outcomes in the form of performance-based competencies created from a shared understanding of what the 'practice-ready graduate' should know, understand, and be able to do (Wright et al., 2018). The result is a practice-focused curriculum where classroom learning activities, including student reflection, group case analyses, and role-play, are used to 'situate' the learning into a pharmacy practice context, with rubrics developed to guide assessment and inform students about expectations. As part of the [redacted curriculum name], a series of courses were developed that would span the entirety of each term and deliver topics that integrate material learned in other courses into a 'realworld' framework. Longitudinal 1 was the first in that series of courses, delivered for the first time in the autumn of 2017 to students in their first professional year. This course integrates social and administrative sciences, therapeutics, and the PPCP focusing on how patients and pharmacists navigate the healthcare system, including content related to payment structures, legal and regulatory aspects, the patient needs assessment, advocacy, and communication with providers, patients, and caregivers. Prior to the development of this curriculum, content related to the social and administrative sciences was taught in a series of stand-alone courses that did not integrate therapeutics or the PPCP. In the autumn of 2018, a new activity, termed the Longitudinal Patient Case assignment (LPC), was integrated to provide students with a formalised mechanism for synthesising content longitudinally across the course in the context of a patient case they created. This assignment also served as one of the most culminating assessments for the course.

The faculty team that conceptualised the assignment included the course coordinator, one of the course instructors, and the Director of Assessment. Key concepts integrated into the assignment are listed in Table I. Students selected one of eight hypothetical patient personas based on brief biographies, depicted in Figure 1. Students developed their patient's story across the term, integrating new content as it was introduced and addressing guiding questions related to the case. The questions required students to problem solve and critically evaluate solutions to manage their patients' challenges navigating the healthcare system, playing the part of the pharmacist. The creation of the patient's story was required of learners in this assignment to solidify the content and create an opportunity for students to explore creative problemsolving with regard to patients and pharmacists navigating the complexities of the US healthcare system. In this assignment, students were given only a few demographic details about their assigned patient persona, such as sex, age, disease state, and hometown (Figure 1) and were tasked with creating the patient's story as they navigated the healthcare system. Students then generated a narrated PowerPoint to relate the accounts of their patients, thus accomplishing both story creation and dialogue through verbal communication. Stories were also told visually through slides containing text and graphics. The 
overall assignment, utilising peer evaluation and selfreflection, tasked students with accomplishing five pedagogical approaches, which included critical thinking, creative thinking, problem-solving, reasoning, and decision-making, prompting students to delve deeper than rote recall or recognition to think and act as a pharmacist providing patient care (Svinicki \& McKeachie, 2014).

Table I: Guiding questions mapped to rubric domains

\begin{tabular}{|c|c|}
\hline Rubric domain & Assignment instructions \\
\hline Healthcare setting description & $\begin{array}{l}\text { Introduce your patient and describe the practice setting in which you first encountered him or her. Be } \\
\text { sure to provide sufficient context in your introduction to the patient in order to understand the patient's } \\
\text { situation. }\end{array}$ \\
\hline Health insurance & $\begin{array}{l}\text { Describe your patient's financial situation and describe his or her medical and prescription drug coverage } \\
\text { (identify whether it is public or private insurance and who is the payer for medical services, any needed } \\
\text { medical devices and prescription drugs). }\end{array}$ \\
\hline Patient background & Describe your patient's living situation and quality of life. \\
\hline Barriers to care & Describe barriers to care the patient is experiencing (you must include at least three barriers to care). \\
\hline Resources to overcome barriers & $\begin{array}{l}\text { Identify and justify the resources that you recommended to your patient to address his or her barriers to } \\
\text { care. }\end{array}$ \\
\hline Resource utilisation & $\begin{array}{l}\text { Describe how you assisted the patient in accessing those resources and how the patient used the } \\
\text { resource to overcome the barrier. }\end{array}$ \\
\hline Counselling & $\begin{array}{l}\text { Your patient is being prescribed a medication that they have never received before. Explain how you } \\
\text { counselled the patient on this new prescription. Be sure to describe how you will incorporate appropriate } \\
\text { patient-centred communication. }\end{array}$ \\
\hline Applying law & $\begin{array}{l}\text { Describe how one law that has affected the healthcare system has also affected your patient as they } \\
\text { interact with the healthcare system. Summarise the law and how it has affected the patient's healthcare } \\
\text { experience. }\end{array}$ \\
\hline Referral & $\begin{array}{l}\text { Your patient needs a referral to another healthcare provider. Explain the need for referral and describe } \\
\text { the interaction between you and that healthcare provider to coordinate patient care. Describe the } \\
\text { healthcare setting in which the patient is seen by the other HCP. }\end{array}$ \\
\hline Advocacy & $\begin{array}{l}\text { A few months after the patient receives the new prescription, you discover that they are non-adherent } \\
\text { because they can no longer afford it. How do you advocate for the patient to get the medication adjusted } \\
\text { to a lower-cost alternative? }\end{array}$ \\
\hline Follow-up/plan & $\begin{array}{l}\text { Summarise your care of the patient and what you will do on an ongoing basis to follow up on his or her } \\
\text { care. Identify any additional clinical services you as the pharmacist can provide and who would pay for } \\
\text { these services. }\end{array}$ \\
\hline
\end{tabular}
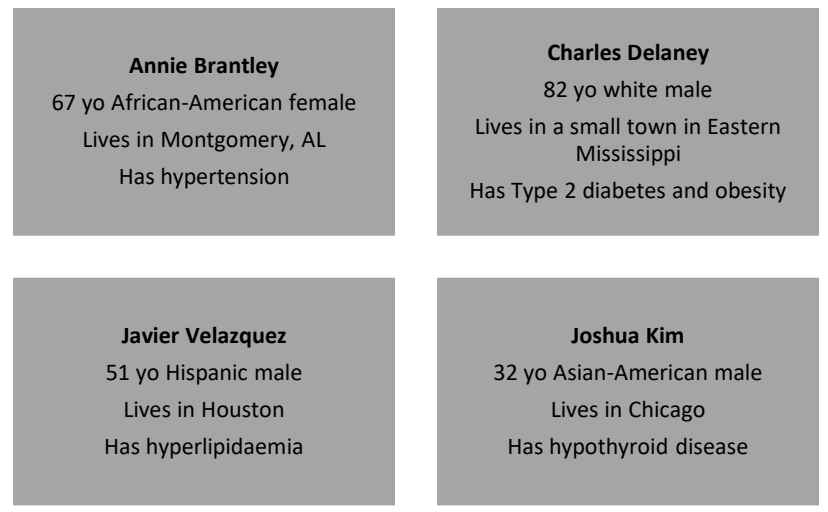
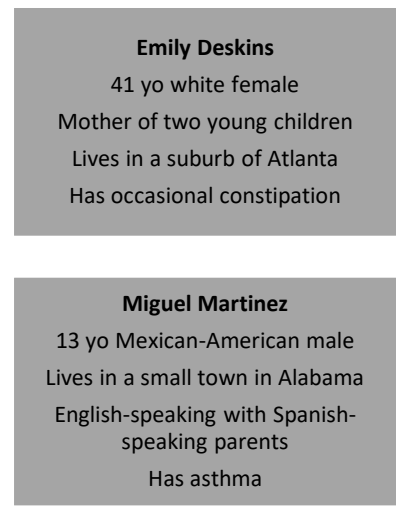
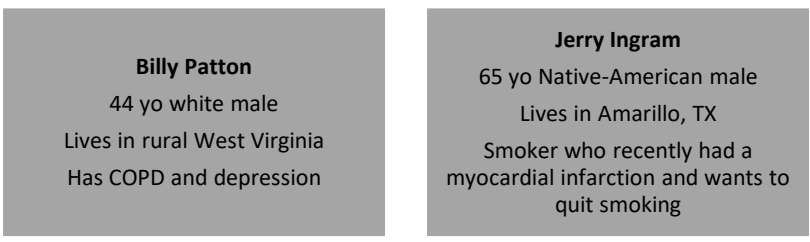

Figure 1: Patient personas 


\section{Grading approach and training}

Due to the complexity of the assignment and to allow for multiple graders, the development team designed and refined grading rubrics to be used to assess students' submissions. Three of the authors who led course development, assessment, and coordination collaborated to develop the grading rubric and map each item to core curricular competencies. Feedback was obtained from the teaching faculty, and revisions were made in several iterations to address clarity, comprehensiveness, relevance to course content, and the interconnectedness of concepts across the term. The LPC rubric (Appendix A) included three standards (met, partially met, not met) and 14 criteria areas directly linked to each slide in the PowerPoint and tagged to the overarching curriculum competencies listed in Table II. Students received the rubric as part of the assignment instructions and were encouraged to use it to self-evaluate their assignment prior to final submission. The final narrated PowerPoint was graded using the LPC rubric by a team of graders, including course faculty and staff, teaching assistants, and pharmacy residents. To promote consistency and reduce ambiguity among graders, each associated criterion and standard on the rubric included specific descriptions to provide pre-determined cut-points. A mandatory training session occurred to prepare graders, introducing the assignment and explaining the grading rubric. As a final step, development team members conducted quality checks prior to releasing students' grades.

\section{Self-reflections/Peer feedback}

As a component of the assignment, the development team incorporated both peer and self-assessment components to enhance overall student learning. Shortly before narrated PowerPoints were completed, students were randomly assigned to conduct a peer review on another student's submission. Peer graders did not necessarily review the same assigned persona. The peerreview had two purposes: 1) to provide the learner with feedback aside from that of the instructor and course personnel, and 2) to evaluate the peer grader's ability to provide quality feedback. An added benefit of this aspect of the assignment is that it provided a benchmark to keep students from waiting until just before the final deadline to start working on their case. Using elements of the LPC rubric, each peer grader evaluated their peer's assignment using the outlined criteria and provided written feedback for each assessment area. This feedback was shared with their peers, with the expectation that improvements would be made before the final submission. Points awarded for the assignment were based on the quality of the peer grader feedback and not on the outcome of the evaluation itself (Appendix B). This strategy was chosen to create a safe space for peer grader review without impacting the course grade of the peer receiving feedback, an important consideration given the relative inexperience of peer graders at this early stage in the curriculum. Lastly, upon receiving peer grader feedback, students were asked to self-reflect on the feedback provided in the form of a written reflection. Reflections were a minimum of 500 words, and students were tasked with discussing the development of their patient's story, reacting to their peer grader's feedback, and exploring how this experience and feedback would shape how they completed projects in the future. Points for the selfreflection assignment were awarded based on the quality of the reflection, and students were provided with a separate self-assessment grading rubric before submission so they would be familiar with the grading criteria (Appendix C).

The objective of the paper was to assess performance and critical thinking skills and explore student perceptions of a Longitudinal Patient Case assignment that integrates knowledge from multiple domains into a learning experience exploring how patients and pharmacists navigate the complexities of the US healthcare system.

\section{Methods}

All first-year student pharmacists enrolled in the Longitudinal 1 course in the autumn term of 2018 were eligible to participate. Data for this study were collected over the duration of that autumn term.

\section{Quantitative data analysis}

Quantitative data sources included overall scores on the narrated PowerPoint (out of 140 points possible), scores for each rubric domain, midterm and final examination scores (each out of 150 points possible), and final course grades (out of $100 \%$ ). Descriptive statistics were used to summarise the data, and Pearson's correlation coefficients were used to measure associations between variables. IBM SPSS Statistics software version 25 was used for the analysis.

\section{Qualitative data sources}

Self-reflections served as the qualitative data source and were de-identified prior to analysis. These data represented the entire population of first-year student pharmacists and provided robust data for analysis. Therefore, there was no sampling. Each of the four researchers, three of whom comprised the development team, were randomly assigned one-fourth of the reflections to analyse independently. The research team reconciled their collective findings and synthesised the codes and themes into one codebook (Roberts et al., 2019). 


\section{Table II: Grading rubric mapped to student learning outcomes}

\begin{tabular}{|c|c|c|c|c|c|c|c|c|c|c|c|c|c|c|}
\hline \multirow{2}{*}{$\begin{array}{l}\text { Student learning outcomes } \\
\text { Competency }\end{array}$} & \multicolumn{14}{|c|}{ Grading rubric elements } \\
\hline & 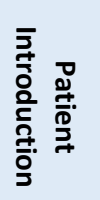 & 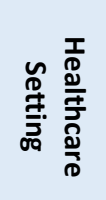 & 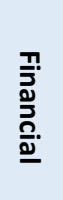 & 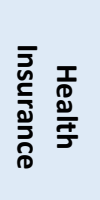 & 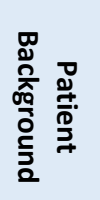 & 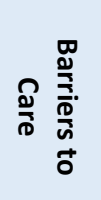 & 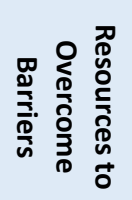 & 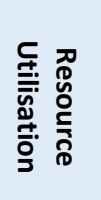 & 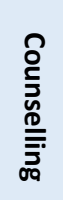 & 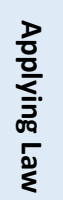 & 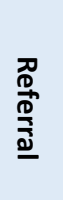 & 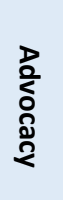 & $\begin{array}{l}\text { 등 꿍 } \\
\frac{0}{0} \\
\frac{0}{J}\end{array}$ & 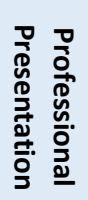 \\
\hline Identify barriers to patient follow-up & & & & & & $x$ & & & & & & & & \\
\hline $\begin{array}{l}\text { Identify barriers to education including cultural, physical, technical, economic, } \\
\text { language, educational }\end{array}$ & & & & & & $\mathrm{x}$ & & & & & & & & \\
\hline Determine patient/caregivers current level of understanding & & & & & & & & & $x$ & & & & & \\
\hline Evaluate the patient quality of life or satisfaction with therapy & & & & & $x$ & & & & & & & & & \\
\hline Determine patient-specific healthcare needs/resources & & & & & & & $x$ & $x$ & & & & & & \\
\hline Identify pharmacoeconomic issues with pharmacotherapy & & & & & & $x$ & & & & & & & & \\
\hline Identify methods to minimize barriers to care & & & $x$ & & & $x$ & $x$ & & & & & & & \\
\hline $\begin{array}{l}\text { Identify resources to address individual patient needs (e.g. patient assistant } \\
\text { programs, discount programs, indigent clinics, etc.) }\end{array}$ & & & & & & & $\mathrm{x}$ & & & & & & & \\
\hline Develop monitoring/follow-up care plans & & & & & & & & & & & & & $\mathrm{x}$ & \\
\hline Demonstrate appropriate communication skills with patients/caregivers & $x$ & & & & & & & & & & & & & \\
\hline Utilize appropriate communication style for patients/audience/situation & & & & & & & & & $\mathrm{x}$ & & & $\mathrm{x}$ & & $x$ \\
\hline Communicate professionally (language, demeanour, social media) & & & & & & & & & & & $x$ & & & \\
\hline Adapt communication for patient's level of understanding/health literacy & & & & & & & & & $\mathrm{x}$ & & & & & \\
\hline Educate patients about therapy & & & & & & & & & $x$ & & & & & \\
\hline Demonstrate effective presentation skills & $x$ & & & & & & & & & & & & & $\mathrm{x}$ \\
\hline $\begin{array}{l}\text { Determine understanding of stakeholders through the use of evidence-based } \\
\text { techniques (e.g. teach-back method, open-ended questions, multiple-choice } \\
\text { questions, active learning, case-based discussion) }\end{array}$ & & & & & & & & & $\mathrm{x}$ & & & & & \\
\hline Utilise system resources & & & & & & & $\mathrm{x}$ & & & & $x$ & & & \\
\hline $\begin{array}{l}\text { Explain the difference in the payment structures between the products and } \\
\text { services }\end{array}$ & & & & $x$ & & & & & & & & & & \\
\hline Examine areas of strength and weakness in the US healthcare system & & $\mathrm{x}$ & & & & & & & & & & & & \\
\hline Summarise information relevant to advocacy to colleagues & & & & & & & & & & & & $x$ & & \\
\hline
\end{tabular}




\section{Thematic analysis}

Qualitative inquiry allows researchers to better understand complex phenomena experienced by participants (Castleberry \& Nolen, 2018). Because the LPC self-reflections offer insight into participants' thoughts and perceptions, qualitative inquiry was utilised to examine these data. Thematic analysis is characteristic of qualitative inquiry (Castleberry \& Nolen, 2018) and can occur through multiple phases. As such, thematic analysis of LPC self-reflections occurred through a multi-phase approach with an interpretivist lens (O'Brien et al., 2014), meaning the investigators leveraged their personal understandings of the course and assignment to analyse and interpret students' experiences and perceptions. Each investigator analysed 38 reflections independently. Although each investigator's codes were slightly different, which is to be expected, each contained the same basic components agreed upon before coding began: inductive codes grouped into broader themes. After independent codes were created, the research team synthesised their independent findings into one final codebook (Table III) (Roberts et al., 2019), which assists with the confirmability and credibility of the findings (Bush \& Amechi, 2019). After the final synthesised codebook was generated, the team defined each subtheme. The last step in generating the investigators' final codebook was the inclusion of supporting quotations to serve as examples of each theme. The study protocol and use of the data were approved by Auburn University's Institutional Review Board.

Table III: Combined codebook

\begin{tabular}{|c|c|c|c|}
\hline Theme & Sub-theme & Description & Quote(s) \\
\hline \multirow[t]{11}{*}{$\begin{array}{l}\text { Project } \\
\text { execution }\end{array}$} & \multirow{3}{*}{$\begin{array}{l}\text { Best practices/ } \\
\text { Strategies/ Helpful } \\
\text { hints }\end{array}$} & \multirow{3}{*}{$\begin{array}{l}\text { Effective strategies for } \\
\text { completion of the } \\
\text { project that serve as } \\
\text { guidance for future } \\
\text { application. To include } \\
\text { advice for future project } \\
\text { completers and ideas } \\
\text { for best practices. }\end{array}$} & $\begin{array}{l}\text { "One thing I could have been more disciplined in was being consistent in } \\
\text { working on my case." }\end{array}$ \\
\hline & & & $\begin{array}{l}\text { "In the future I will need to be more alert when turning in my assignments } \\
\text { to ensure that the correct file is uploaded." }\end{array}$ \\
\hline & & & $\begin{array}{l}\text { "I will make it a point of thinking outside of my own little box when making } \\
\text { presentations in the future. I am not going to be presenting to people who } \\
\text { are exactly like me, so I need to have a more well-rounded presentation } \\
\text { that a wealth of viewers would enjoy." }\end{array}$ \\
\hline & \multirow[t]{4}{*}{$\begin{array}{l}\text { Challenges/ } \\
\text { Execution/ Barriers }\end{array}$} & \multirow{4}{*}{$\begin{array}{l}\text { Perceived logistical } \\
\text { issues that students } \\
\text { encountered across the } \\
\text { project to include } \\
\text { timeliness, technical } \\
\text { difficulties, uncertainty, } \\
\text { and at times creative } \\
\text { freedom. }\end{array}$} & $\begin{array}{l}\text { "By far the most difficult part of this assignment was having to narrate the } \\
\text { PowerPoint." }\end{array}$ \\
\hline & & & "I had stage fright even though no one was in front of me." \\
\hline & & & $\begin{array}{l}\text { "I struggled with how much free reign I had over this assignment...I found } \\
\text { myself hitting a brick wall creativity." }\end{array}$ \\
\hline & & & $\begin{array}{l}\text { "I didn't fully understand the direction I was supposed to take in this } \\
\text { assignment." }\end{array}$ \\
\hline & \multirow[t]{4}{*}{$\begin{array}{l}\text { Facilitators/ } \\
\text { Support } \\
\text { mechanisms }\end{array}$} & \multirow{4}{*}{$\begin{array}{l}\text { Student identified } \\
\text { resources and strategies } \\
\text { utilized throughout the } \\
\text { semester to assist with } \\
\text { project development. To } \\
\text { include at times creative } \\
\text { freedom, class notes, } \\
\text { journaling, rubric } \\
\text { guidance, and planning } \\
\text { (i.e. concept mapping, } \\
\text { outlines, etc.) }\end{array}$} & $\begin{array}{l}\text { "This project as a whole required me to look at my notes many times to } \\
\text { ensure I was getting the information right, not just with insurance, } \\
\text { therefore I felt like I was studying while creating this story." }\end{array}$ \\
\hline & & & $\begin{array}{l}\text { "Once a unit was taught in class, I would go home that week and try to } \\
\text { finish the corresponding slide so that the material was fresh on my mind." }\end{array}$ \\
\hline & & & $\begin{array}{l}\text { "Once I had started the case, I actually found joy in being able to be } \\
\text { creative with this assignment, which is not something that I am able to do } \\
\text { very often in pharmacy school." }\end{array}$ \\
\hline & & & $\begin{array}{l}\text { "The rubric helped me to organize my thoughts and understand the needed } \\
\text { information." }\end{array}$ \\
\hline \multirow[t]{5}{*}{$\begin{array}{l}\text { Learning / } \\
\text { knowledge }\end{array}$} & \multirow[t]{2}{*}{ Critical thinking } & \multirow{2}{*}{$\begin{array}{l}\text { Students' ability to } \\
\text { integrate knowledge, } \\
\text { skills, and abilities to } \\
\text { identify and solve } \\
\text { problems at a higher } \\
\text { level. }\end{array}$} & $\begin{array}{l}\text { "I realized that I have struggled many times with how deeply I do not think. } \\
\text { I tend to think on the surface level of content" }\end{array}$ \\
\hline & & & $\begin{array}{l}\text { "It offered me a way to make connection between the material and see } \\
\text { how these objectives are prevalent in each patient's life" }\end{array}$ \\
\hline & \multirow[t]{3}{*}{$\begin{array}{l}\text { Comfort with } \\
\text { uncertainty }\end{array}$} & \multirow{3}{*}{$\begin{array}{l}\text { Students' acceptance of } \\
\text { operating outside their } \\
\text { comfort zone and } \\
\text { recognition that } \\
\text { multiple answers may } \\
\text { be acceptable. }\end{array}$} & $\begin{array}{l}\text { "I really liked being in control of the story and having free rein [sic] in } \\
\text { creating a story for my patient." }\end{array}$ \\
\hline & & & $\begin{array}{l}\text { "I will continue to work on my confidence level by practicing speaking in } \\
\text { front of people more often." }\end{array}$ \\
\hline & & & $\begin{array}{l}\text { "The fact that we did not have many strict rules when it comes to our } \\
\text { patients made it tough, but interesting and entertaining at the same time." }\end{array}$ \\
\hline
\end{tabular}




\begin{tabular}{|c|c|c|c|}
\hline Theme & Sub-theme & Description & Quote(s) \\
\hline & \multirow[t]{2}{*}{ Application } & \multirow{2}{*}{$\begin{array}{l}\text { Students' ability to } \\
\text { utilise knowledge } \\
\text { gained to complete a } \\
\text { task. }\end{array}$} & $\begin{array}{l}\text { "I believe this assignment was very helpful for learning the material, and I } \\
\text { think it should be used for future first year pharmacy students." }\end{array}$ \\
\hline & & & $\begin{array}{l}\text { "Pharmacy is an incredible field of work and I can't wait to use what I have } \\
\text { learned while completing this assignment in the real world." }\end{array}$ \\
\hline
\end{tabular}

Appropriate with qualitative inquiry, the researchers acknowledge their influences, backgrounds, and positions as it relates to the creation and implementation of the LPC and analysis of findings in the present study. The research team believes that knowledge is constructed through assignments such as the LPC because it is designed to facilitate critical thinking and cultivate self-directed learners since students were expected to synthesise course information over time by developing a coherent, believable patient case. This belief and potential bias, and the influence it may have on the study outcomes, was transparently noted through active reflection and frequent dialogue among the team. Researchers acknowledge that the qualitative findings reflect the context in which they occurred, thus limiting the transferability of the results to other contexts (Amin et al., 2020).

\section{Results}

All first-year student pharmacists $(n=153)$ participated in the LPC assignment, as well as the self-reflection. The mean score on the case was $134 / 140$ (95.7\%) with a range of $78.9 \%-100 \%$; the majority $(n=104)$ of students scored $96.4 \%$ or higher; one-third of the class $(n=50)$ scored $100 \%$. Scores on the case were significantly, though modestly, correlated with midterm examination scores $(r=0.257, p=0.001)$ and final examination scores $(r=0.201$; $p=0.013$ ), and were moderately correlated with overall course grades $(r=0.496, p<0.001)$, based on Cohen's guideline of Pearson's $r$ of $0.1,0.3$, and 0.5 representing small, medium, and large effect sizes, respectively (Cohen, 1988). Mean scores on each domain of the rubric are listed in Table IV. The domain with the lowest mean score (mean=8.37/10) was Professional Presentation.

Several themes evolved from the qualitative analyses of the students' self-reflections; however, for the purposes of this manuscript, the authors will focus on those directly related to the assignment and associated learning outcomes. Additional themes have been previously published (Garza et al., 2021). The two themes presented here focused on project execution (to include the subthemes best practices/ strategies/ helpful hints, challenges/ execution/ barriers, and facilitators/ support mechanisms) and learning/ knowledge (to include the subthemes critical thinking, comfort with uncertainty, and application) (Table III).
Table IV: Longitudinal case narrated PowerPoint mean scores for each domain and overall*

\begin{tabular}{lccc}
\hline & Mean (SD) & Minimum & Maximum \\
\hline Patient introduction & $9.90(0.70)$ & 5 & 10 \\
$\begin{array}{l}\text { Healthcare setting } \\
\text { description }\end{array}$ & $9.48(1.64)$ & 0 & 10 \\
Financial & $9.64(1.30)$ & 5 & 10 \\
Health insurance & $9.74(1.12)$ & 5 & 10 \\
Patient background & $9.67(1.24)$ & 5 & 10 \\
Barriers to Care & $9.97(0.40)$ & 5 & 10 \\
Resources to & $9.80(0.97)$ & 5 & 10 \\
overcome barriers & & & \\
Resource utilisation & $9.51(1.49)$ & 5 & 10 \\
Counselling & $9.67(1.24)$ & 5 & 10 \\
Applying law & $9.93(0.57)$ & 5 & 10 \\
Referral & $9.08(1.94)$ & 5 & 10 \\
Advocacy & $9.90(0.70)$ & 5 & 10 \\
Follow-up/plan & $9.51(1.49)$ & 5 & 10 \\
Professional & $8.37(2.68)$ & 0 & 10 \\
presentation & & & \\
\hline Total score & $\mathbf{1 3 3 . 9 7}$ & $\mathbf{1 1 0 . 5}$ & \\
(out of 140) & $\mathbf{5 . 9 5 )}$ & & \\
\hline Points possible ranged from 0 to 10 for each domain & \\
\hline
\end{tabular}

One student noted that "because of this project and the peer review that we had to complete afterwards, I have really started to look at the way I will go about completing these projects in the future" [best practices/strategies/helpful hints]. The authors found that while students appreciated the freedom the project provided, some students felt at the same time that the freedom was actually difficult to overcome; "I struggled with how much free reign I had over this assignment...l found myself hitting a brick wall creativity [sic]" [comfort with uncertainty]. Yet, many students appreciated the self-directed nature of the assignment, with one reflecting "...the creating of my progressive case gave me an opportunity to tie in several topics discussed throughout the semester that seemed disjointed at first by applying them all to one patient scenario" [critical thinking]. Lastly, students were able to take what they learned in class and apply it to future clinical practice; "I believe this assignment really made me apply what we learned in this class to a real-world situation..." [application]. 
Feedback provided by peer graders was described by many as helpful, as was the process of giving peer feedback; "Overall, my peer review was extremely helpful. The comments and clear feedback really helped me learn from my progressive case." Students also commented that the assignment was beneficial in allowing them to assimilate content across the course, and they anticipated that the experience would help them apply their knowledge in their future clinical practice. One student noted, they "...learned the importance of peer feedback because some of the areas of improvement were details that I did not even consider when developing the case."

\section{Discussion}

A Longitudinal Patient Case assignment was designed to help students assimilate and apply information learned in a first-year, first-semester pharmacy school course on navigating the US healthcare system. Students used critical thinking and self-reflection to create a patient story, including required components reflecting the breadth of course content. Quantitative data analysis revealed a high level of performance on the narrated PowerPoint segment of the assignment, with most students receiving scores of $96 \%$ or more, and a correlation between assignment scores and other course assessments designed to measure grasp of similar content. High scores on the assignment are likely due to the extended period of time students had to work on their case, feedback received from the peer review process, and the ability to utilise notes and other course resources. Qualitative analysis revealed that some students struggled with the freedom the project afforded, while others appreciated the opportunity to be creative. By placing students into the context of a pharmacist directly caring for a patient, telling their stories and solving problems early on in the curriculum, this assignment allowed students to better identify with the role of the pharmacist early in the curriculum with the goal of building on this identity as they progress. Taken together, the researchers surmise that the project assisted the students with content integration and overall knowledge acquisition of course concepts while also promoting self-directedness and critical thinking by encouraging creativity and application when uncertain.

Grading of the narrated PowerPoint presentations for the assignment was accomplished systematically and objectively using a rubric, grader training, and assessment quality checks by course faculty. The high level of student performance on the assignment indicates student success in applying the required components to a patient scenario. Given that the midterm and final examinations and the LPC were all summative assessments designed to evaluate student achievement of the competencies, it is not surprising that there was a correlation in student performance among these assessments. Although modest, the correlation between assignment scores and course midterm and final examinations suggest the validity of the assignment to assess student knowledge and application of the content related to course competencies, such as identifying healthcare-related resources to address individual patient needs. The assignment provided students with an opportunity to practise assessing a patient's healthcare situation and barriers to care in a systematic way, while also providing a way for faculty to assess the students on these skills. Performance on the assignment was moderately correlated with overall course performance, further supporting the utility of the assignment to assess student learning accurately, taking into consideration that the assignment did comprise $14 \%$ of the final course grade.

Data collected from self-reflections showed variability in students' preferences, with some appreciating the flexibility allowed, while others would have preferred more structure and guidance for developing the assignment. However, studies have found that student learning is improved when students are challenged within the learning environment, specifically when tasked with cognitively complex and challenging activities (Hamari et al., 2016). According to Hamari and colleagues, "when invited to engage in complex problem solving instead of confronting topics only superficially, students see more connections, become more intrinsically interested, and thus pay better attention" (2016, p. 171). Learning experiences such as this can build critical thinking by intentionally providing students with the opportunity to engage in complex thinking (Persky et al., 2019). Analysis of self-reflections showed that students were able to think critically to apply knowledge learned throughout the semester to their patient's story. This level of problem-solving and critical thinking supports the inclusion of learning experiences, such as this one, early in pharmacy curricula. The flexibility and creativity afforded to students in this assignment created some unease in certain students, forcing them out of their comfort zones. This outcome is also important, as creating unease can help students become more comfortable with the uncertainties related to healthcare and prepare them for the adaptability needed in professional practice. This assignment challenged students not only to identify problems patients may experience within the healthcare system, but also create solutions. Students had to consider other healthcare team members, therefore establishing foundational building blocks to embrace working as a 
team to provide the best clinical, economic, and humanistic outcomes. By challenging students to imagine patient scenarios, problems, and solutions, the assignment prepared students early in the curriculum to focus on patient and professional advocacy while solving patient-related problems in professional practice. Providing this exposure early also encourages students to continue to focus on and hone these skills as they progress throughout the didactic and experiential curriculum, so they are practice-ready at the time of graduation.

Learning must be connected to students' lives to foster retention and meaning-making (Paolini, 2015). The integration of the LPC assignment allowed faculty to establish this connection, pushing students to employ critical and creative thinking towards the application of knowledge to shape how they will serve patients once they enter into practice. The patient case, peer feedback assignment, and self-reflection thus provided the foundation needed to establish maximum learning in this course (Paolini, 2015). In accordance with the 4step approach proposed by Persky and colleagues, students identify a problem in their patient associated with a barrier (generation), define or describe this problem (conceptualisation), evaluate and design a plan to address the identified barrier (optimisation), and then describe the action taken to implement the plan (implementation) (Persky et al., 2019). This cycle can be used alongside the PPCP, as is done with the LPC. As noted, the design of the LPC tasked students with identifying the need to problem solve and think critically when developing their patient case. This result serves as evidence that this cycle was beginning to develop critical thinking skills in these students.

The inclusion of the peer feedback assignment within the broader LPC assignment offered students the opportunity to utilise what they had learned over the course of the term to provide feedback to their peers. This assignment intended to provide first-year, firstterm pharmacy students with a relaxed and safe environment for delivering feedback early in the curriculum, to allow students to see what other students had developed, and to provide pointed feedback to help their peers improve on future assignments. As an added benefit, it prompted students to avoid waiting until just before the due date to begin putting their case together. By receiving peer grader and instructor feedback, students had multiple perspectives to reflect upon and could utilise this feedback on future assignments (Bubb, 2012; Svinicki \& McKeachie, 2014). The inclusion of multiple perspectives promotes student understanding and should lead to improvement over time. The immense value of this peer review process prompted the course coordinator in subsequent offerings of the course to include an additional peer review earlier in the semester, giving students two rounds of feedback and prompting them to begin thinking about the case much earlier in the semester.

Peer feedback is only one feedback mechanism, and students should also be encouraged to self-assess through active reflection. Svinicki and McKeachie comment that as students complete independent assignments, they are actively generating what they call an inner dialogue (also referred to as reflective dialogue) and feedback (2014). "These inner or reflective dialogues are a natural consequence of engaging in any purposeful action" (Svinicki \& McKeachie, 2014, p. 119). Students may not recognise the value of self-reflection; however, the emergent themes collected during the qualitative analysis showed that students were transitioning into independent thinkers and were able to critically apply concepts to formulate a comprehensive plan for their patients. This step is essential in health education, preparing students to become critical and independent thinkers in the experiential setting and ultimately in professional practice. The data also provided faculty with significant insight into the overarching impact of the assignment for student learning and strategies for improving the learning experience for future cohorts.

\section{Strengths and limitations}

Strengths of this evaluation include the relatively large data set collected from all students enrolled in the course. Robust student feedback through selfreflection provided a large set of qualitative data from each student, which serves as a form of data triangulation (Bush \& Amechi, 2019). Despite these strengths of the evaluation, results should be interpreted with caution in light of several limitations. There was no control group or pre-post comparison of outcomes. Correlations between assignment scores and course examinations, although statistically significant, were modest in effect size. Qualitative data were evaluated in parts by each of the researchers who also contributed to the development of the assignment, potentially influencing data analysis and interpretation. The data of only one year were collected, limiting the ability to evaluate improvement in the effectiveness of the assignment over time resulting from modifications. Likewise, there was no evaluation of how much knowledge students retained as they progressed through the curriculum. Future evaluations should include multiple student cohorts and follow students through the curriculum to measure knowledge retention. 


\section{Conclusion}

In conclusion, the LPC assignment was developed to facilitate student learning through a longitudinal, selfdirected case experience, showing that synthesising and applying content from across a course in this manner enabled students to successfully make connections, think critically, and be creative as indicated by performance on assessments. The results also showed that, while challenging, students generally appreciated the complexity and creativity associated with the learning experience. Considering the difficulty associated with integrating content from social, behavioural, and/or administrative sciences and teaching it in a manner that fosters student cognition and growth, the details provided herein may offer a pedagogical option to prepare students for pharmacy practice through cohesive integration of this content with clinical practice skills while fostering critical thinking, creative thinking, problem-solving, reasoning, and decision-making.

\section{Declaration of interest statement}

The authors declare no conflict of interest associated with this work.

\section{Financial disclosure}

This research did not receive any specific grant from funding agencies in the public, commercial, or not-forprofit sectors.

\section{Contribution to literature}

This study describes the development and implementation of an effective learning experience for student pharmacists in the social, behavioural, and administrative sciences. The assignment is unique in that students create a patient's story and use selfreflection to demonstrate knowledge related to the patient experience when navigating the United States healthcare system. Results of the study indicate that synthesising and applying content from across a course in this manner enables students to make connections, think critically, and be creative.

\section{References}

Accreditation Council for Pharmacy Education. (2015, February 2). Accreditation Standards and Key Elements for the Professional Program in Pharmacy Leading to the Doctor of Pharmacy Degree ("Standards 2016"). https://www.acpeaccredit.org/pdf/Standards2016FINAL.pdf

Amin, M., Norgaard, L.S., Cavaco, A.M., Witry, M.J., Hillman, L., Cernasev, A., et al. (2020). Establishing trustworthiness and authenticity in qualitative pharmacy research. Research in Social and Administrative Pharmacy, 16(10), 1472-1482. https://doi.org/10.1016/j.sapharm.2020.02.005

Bubb, R. (2012). Assessing student learning. In W. Buskist, \& V.A. Benassi (Eds), Effective college and university teaching: Strategies and tactics for the new professoriate (pp. 115124). Thousand Oaks, CA: Sage Publications, Inc. https://doi.org/10.4135/9781452244006.n13

Bush, A.A., \& Amechi, M.H. (2019). Conducting and presenting qualitative research in pharmacy education. Currents in Pharmacy Teaching and Learning, 11(6), 638650. https://doi.org/10.1016/j.cptl.2019.02.030

Castleberry, A., \& Nolen, A. (2018). Thematic analysis of qualitative research data: Is it as easy as it sounds? Currents in Pharmacy Teaching and Learning, 10(6), 807-815. https://doi.org/10.1016/j.cptl.2018.03.019

Cohen, J. (1988). Statistical power analysis for the behavioral sciences ( $2^{\text {nd }}$ ed.). Hillside, NJ: Lawrence Erbaum Associates

Garza, K.B., Moseley, L.E., Wright, B.M., \& Ford, C.R. (2021). Evaluating the impact of a longitudinal patient case on the development of professionalism and professional identity. New Directions for Teaching and Learning, 89-101. https://doi.org/10.1002/tl.20471

Hamari, J., Shernoff, D.J., Rowe, E., Coller, B., Asbell-Clarke, J., \& Edwards, T. (2016). Challenging games help students learn: An empirical study on engagement, flow and immersion in game-based learning. Computers in Human Behavior, 54, 170-179. https://doi.org/10.1016/j.chb.2015.07.045

Joint Commission of Pharmacy Practitioners. (2014, May 29). Pharmacists' patient care process. Retrieved November 4, 2021from https://jcpp.net/wp-

content/uploads/2016/03/PatientCareProcess-withsupporting-organizations.pdf

Nerali, J., Telang, L., Telang, A., \& Chakravarthy, P. (2016). The role of self-directed learning in problem-based learning: Health professions education. Archives of Medicine and Health Sciences, 4(1), 125-126. https://doi.org/10.4103/2321-4848.183364

O'Brien, B.C., Harris, I.B., Beckman, T.J., Reed, D.A., \& Cook, D.A. (2014). Standards for reporting qualitative research: a synthesis of recommendations. Academic Medicine, 89(9), 1245-1251.

https://doi.org/10.1097/ACM.0000000000000388

Paolini, A. (2015). Enhancing teaching effectiveness and student learning outcomes. Journal of Effective Teaching, 15(1), 20-33

Persky, A.M., Medina, M.S., \& Castleberry, A.N. (2019). Developing critical thinking skills in pharmacy students. American Journal of Pharmaceutical Education, 83(2), 7033. https://doi.org/10.5688/ajpe7033 
Piaget, J. (1950). Explanation in sociology. In J. Piaget (Ed.), Sociological studies (pp. 30-96). New York, NY: Routledge

Piaget, J., \& Cook, M. (1952). The origins of intelligence in children. New York, NY: International Universities Press

Roberts, K., Dowell, A., \& Nie, J.B. (2019). Attempting rigour and replicability in thematic analysis of qualitative research data: A case study of codebook development. BMC Medical Research Methodology, 19(1), 66.

https://doi.org/10.1186/s12874-019-0707-y

Svinicki, M., \& McKeachie, W. (2014). McKeachie's teaching tips: Strategies, research, and theory for college and university teachers. Belmont, CA: Wadsworth Cengage Learning

Vande Wiele, P., Morris, D., Ribière, V., \& Ermine, J. (2017). Project based learning for professional identity: A case study of collaborative industry projects in marketing. The Independent Journal of Teaching and Learning, 12(2), 44-63. https://journals.co.za/doi/pdf/10.10520/EJC-c4e4139ef

Wright, B.M., Hornsby, L., Marlowe, K.F., Fowlin, J., Surry, D.W. (2018). Innovating pharmacy curriculum through backward design. TechTrends, 62(3), 224-229. https://doi.org/10.1007/s11528-018-0283-8 
Appendix A: Longitudinal patient case grading rubric

\begin{tabular}{|c|c|c|c|}
\hline & Not Met (0) & Partially Met (5) & Met (10) \\
\hline $\begin{array}{l}\text { Patient Introduction } \\
\text { (Slide 1) }\end{array}$ & Did not introduce the patient & $\begin{array}{l}\text { Introduced patient but did not provide } \\
\text { context }\end{array}$ & $\begin{array}{l}\text { Introduced patient and provided } \\
\text { context }\end{array}$ \\
\hline $\begin{array}{l}\text { Healthcare Setting } \\
\text { Description } \\
\text { (Slide } 1 \text { and 9) }\end{array}$ & $\begin{array}{l}\text { Did not describe the settings in } \\
\text { which the patient interacted } \\
\text { with you and other healthcare } \\
\text { providers }\end{array}$ & $\begin{array}{l}\text { Described the settings in which the } \\
\text { patient interacted with you and/or the } \\
\text { other healthcare provider, but missing } \\
\text { key components }\end{array}$ & $\begin{array}{l}\text { Described the setting in which you } \\
\text { interacted with the patient and } \\
\text { described the setting in which the } \\
\text { patient interacted with the other } \\
\text { healthcare provider }\end{array}$ \\
\hline $\begin{array}{l}\text { Financial } \\
\text { (Slide 2) }\end{array}$ & $\begin{array}{l}\text { Did not describe patient financial } \\
\text { situation }\end{array}$ & $\begin{array}{l}\text { Described patient financial situation } \\
\text { but missing key components }\end{array}$ & $\begin{array}{l}\text { Fully described patient financial } \\
\text { situation }\end{array}$ \\
\hline $\begin{array}{l}\text { Health Insurance } \\
\text { (Slide 2) }\end{array}$ & $\begin{array}{l}\text { Did not describe patient's } \\
\text { medical or prescription drug } \\
\text { coverage }\end{array}$ & $\begin{array}{l}\text { Described patient's medical coverage } \\
\text { and/or prescription drug coverage but } \\
\text { missing key components }\end{array}$ & $\begin{array}{l}\text { Fully described patient's medical } \\
\text { coverage AND prescription drug } \\
\text { coverage }\end{array}$ \\
\hline $\begin{array}{l}\text { Patient Background } \\
\text { (Slide 3) }\end{array}$ & $\begin{array}{l}\text { Did not describe patient's living } \\
\text { situation and quality of life }\end{array}$ & $\begin{array}{l}\text { Described patient's living situation OR } \\
\text { quality of life }\end{array}$ & $\begin{array}{l}\text { Described patient's living situation } \\
\text { AND quality of life }\end{array}$ \\
\hline $\begin{array}{l}\text { Barriers to Care } \\
\text { (Slide 4) }\end{array}$ & $\begin{array}{l}\text { Did not identify any barriers to } \\
\text { care }\end{array}$ & Identified $1-2$ barriers to care & $\begin{array}{l}\text { Identified three or more barriers to } \\
\text { care }\end{array}$ \\
\hline $\begin{array}{l}\text { Resources to } \\
\text { Overcome Barriers } \\
\text { (Slide 5) }\end{array}$ & $\begin{array}{l}\text { Did not identify or justify } \\
\text { appropriate resources }\end{array}$ & $\begin{array}{l}\text { Identified appropriate resources but } \\
\text { did not justify selection }\end{array}$ & $\begin{array}{l}\text { Identified appropriate resources and } \\
\text { justification }\end{array}$ \\
\hline $\begin{array}{l}\text { Resource Utilisation } \\
\text { (Slide 6) }\end{array}$ & $\begin{array}{l}\text { Did not develop plan or evaluate } \\
\text { how patient used the resource }\end{array}$ & $\begin{array}{l}\text { Developed resource plan but did not } \\
\text { explain how patient used the resource }\end{array}$ & $\begin{array}{l}\text { Developed resource plan and } \\
\text { described how patient used the } \\
\text { resource }\end{array}$ \\
\hline $\begin{array}{l}\text { Counseling } \\
\text { (Slide 7) }\end{array}$ & $\begin{array}{l}\text { Did not describe counseling and } \\
\text { incorporate patient-centered } \\
\text { communication }\end{array}$ & $\begin{array}{l}\text { Described counseling but description } \\
\text { of patient-centered communication } \\
\text { was flawed }\end{array}$ & $\begin{array}{l}\text { Described counseling and } \\
\text { incorporated patient-centered } \\
\text { communication appropriately }\end{array}$ \\
\hline $\begin{array}{l}\text { Applying Law } \\
\text { (Slide 8) }\end{array}$ & $\begin{array}{l}\text { Did not identify a law and did not } \\
\text { describe how one law affected } \\
\text { patient's healthcare experience }\end{array}$ & $\begin{array}{l}\text { Identified a law but did not summarize } \\
\text { the law OR describe how it affected } \\
\text { patient's healthcare experience }\end{array}$ & $\begin{array}{l}\text { Summarized a law AND described } \\
\text { how it affected patient's healthcare } \\
\text { experience. }\end{array}$ \\
\hline $\begin{array}{l}\text { Referral } \\
\text { (Slide 9) }\end{array}$ & $\begin{array}{l}\text { Did not explain referral and } \\
\text { interaction with the other } \\
\text { healthcare provider }\end{array}$ & $\begin{array}{l}\text { Did not explain referral need OR did } \\
\text { not describe interaction with the } \\
\text { other healthcare provider }\end{array}$ & $\begin{array}{l}\text { Explained referral need and } \\
\text { described interaction with the other } \\
\text { healthcare provider }\end{array}$ \\
\hline $\begin{array}{l}\text { Advocacy } \\
\text { (Slide 10) }\end{array}$ & Did not advocate for the patient & Description of advocacy was flawed & $\begin{array}{l}\text { Described how to advocate for the } \\
\text { patient }\end{array}$ \\
\hline $\begin{array}{l}\text { Follow-up/Plan } \\
\text { (Slide 11) }\end{array}$ & $\begin{array}{l}\text { Did not summarize care and } \\
\text { provide a plan for follow-up }\end{array}$ & $\begin{array}{l}\text { Summarized care OR provided a plan } \\
\text { for follow-up }\end{array}$ & $\begin{array}{l}\text { Summarized care of patient and } \\
\text { provided a plan for follow-up }\end{array}$ \\
\hline $\begin{array}{l}\text { Professional } \\
\text { Presentation }\end{array}$ & $\begin{array}{l}\text { Did not use appropriate } \\
\text { communication (including } \\
\text { language, style, etc.) based on } \\
\text { audience and situation }\end{array}$ & $\begin{array}{l}\text { Inconsistently provided clear, } \\
\text { accurate, evidence-based, and } \\
\text { succinct verbal communication }\end{array}$ & $\begin{array}{l}\text { Consistently provided clear, accurate, } \\
\text { evidence-based, and succinct verbal } \\
\text { communication }\end{array}$ \\
\hline
\end{tabular}

\section{Appendix B: Peer evaluation quality grading instructions}

This assignment will be evaluated for the following:

- Rubric Completeness (every section scored) $-50 \%$

- Written Feedback Completeness (every section feedback provided) - 15\%

- Quality of Written Feedback (Meaningful, Somewhat Meaningful, Not Meaningful) - 35\%

Quality of feedback will be assessed on the strength of the justification of the rubric rating in each section of the rubric. This justification should not be limited to meeting the requirements of the rubric but should also include areas of strength or improvement in every section. 
Appendix C: Quality of self-assessment rubric

\begin{tabular}{|c|c|c|c|c|}
\hline & Needs Development & Novice & Aware Practitioner & Practice Ready/Reflective Practitioner \\
\hline $\begin{array}{l}\text { Relevance to } \\
\text { Situation }\end{array}$ & $\begin{array}{l}\text { Shows no awareness } \\
\text { and/or effort or is } \\
\text { irrelevant to the learning } \\
\text { context. }\end{array}$ & $\begin{array}{l}\text { Shows minimal awareness } \\
\text { and/or effort and is mostly } \\
\text { irrelevant to the learning } \\
\text { context. }\end{array}$ & $\begin{array}{l}\text { Shows awareness and effort; } \\
\text { attempts to demonstrate } \\
\text { relevance, but the relevance is } \\
\text { unclear or superficial in } \\
\text { reference to the learning } \\
\text { context. }\end{array}$ & $\begin{array}{l}\text { Shows significant awareness and effort, } \\
\text { the learning context is being reflected } \\
\text { upon and is relevant and meaningful. }\end{array}$ \\
\hline
\end{tabular}

Comments:

\begin{tabular}{|l||c|c|c||c|}
\hline Analysis & $\begin{array}{c}\text { Does not move beyond a } \\
\text { description of the learning } \\
\text { experience. }\end{array}$ & $\begin{array}{c}\text { Attempts to analyze one's } \\
\text { own performance or } \\
\text { insight acquired through } \\
\text { the learning experience are } \\
\text { vague. }\end{array}$ & $\begin{array}{c}\text { Analysis of one's own } \\
\text { performance or insight } \\
\text { acquired through the learning } \\
\text { experiences is superficial. }\end{array}$ & $\begin{array}{c}\text { Analysis of one's own performance or } \\
\text { insight acquired through the learning } \\
\text { experiences is thoughtful and in-depth. }\end{array}$ \\
\hline
\end{tabular}

Comments:

\begin{tabular}{|l||c||c|c||c|}
\hline $\begin{array}{l}\text { Conceptual } \\
\text { Clarity }\end{array}$ & $\begin{array}{c}\text { Lacks conceptual clarity; } \\
\text { concepts are not discussed } \\
\text { or presented. }\end{array}$ & $\begin{array}{c}\text { Major, frequent lapses in } \\
\text { conceptual clarity. } \\
\text { Concepts are either not } \\
\text { discussed or not presented } \\
\text { accurately. }\end{array}$ & $\begin{array}{c}\text { Minor, infrequent lapses in } \\
\text { conceptual clarity. Most } \\
\text { abstract concepts are } \\
\text { explained accurately. }\end{array}$ & $\begin{array}{c}\text { Conceptual clarity is expressive and } \\
\text { abstract concepts are explained } \\
\text { accurately. The reader can create a } \\
\text { mental picture of the situation/scenario } \\
\text { being described. }\end{array}$ \\
\hline
\end{tabular}

Comments:

\begin{tabular}{|c|c|c|c|c|}
\hline $\begin{array}{l}\text { Professional } \\
\text { Identity }\end{array}$ & $\begin{array}{c}\text { Shows no awareness } \\
\text { and/or effort in identifying } \\
\text { the role of the pharmacist } \\
\text { to the learning context; is } \\
\text { unable to articulate one's } \\
\text { identity as a future } \\
\text { pharmacist. }\end{array}$ & $\begin{array}{c}\text { Shows minimal awareness } \\
\text { and/or effort in identifying } \\
\text { the role of the pharmacist } \\
\text { to the learning context; } \\
\text { struggles to articulate } \\
\text { one's identity as a future } \\
\text { pharmacist. }\end{array}$ & $\begin{array}{l}\text { Attempts to demonstrate } \\
\text { relevance of the role of the } \\
\text { pharmacist, but the relevance } \\
\text { is unclear or superficial in } \\
\text { reference to the learning } \\
\text { context. Superficially } \\
\text { articulates one's identity as a } \\
\text { future pharmacist. }\end{array}$ & $\begin{array}{l}\text { The role of the pharmacist is being } \\
\text { reflected upon and is relevant and } \\
\text { meaningful in regards to the learning } \\
\text { context. Articulates one's identity as a } \\
\text { future pharmacist }\end{array}$ \\
\hline
\end{tabular}

Comments:

\begin{tabular}{|l||c||c|c|c|}
\hline Self-Criticism & $\begin{array}{c}\text { No attempt at self- } \\
\text { criticism. }\end{array}$ & $\begin{array}{c}\text { Some attempt at self- } \\
\text { criticism, but the self- } \\
\text { reflection fails to } \\
\text { demonstrate a new } \\
\text { awareness of personal } \\
\text { biases, etc. }\end{array}$ & $\begin{array}{c}\text { Demonstrates ability to } \\
\text { question their own biases, } \\
\text { stereotypes, preconceptions. } \\
\text { New modes of thinking not } \\
\text { evident. }\end{array}$ & $\begin{array}{c}\text { Demonstrates ability to question their } \\
\text { own biases, stereotypes, } \\
\text { preconceptions, and/or assumptions } \\
\text { and define new modes of thinking as a } \\
\text { result. }\end{array}$ \\
& &
\end{tabular}




\begin{tabular}{|c|c|c|c|c|}
\hline \multicolumn{5}{|l|}{ Comments: } \\
\hline Strengths & $\begin{array}{l}\text { No attempt to identify } \\
\text { strengths within the } \\
\text { learning context. }\end{array}$ & $\begin{array}{l}\text { Some attempt at } \\
\text { identifying strengths, but } \\
\text { struggles to articulate }\end{array}$ & \begin{tabular}{|c|} 
Attempts to identify strengths, \\
but the relevance is unclear or \\
superficial in reference to the \\
learning context.
\end{tabular} & $\begin{array}{l}\text { Clearly identify strengths and how they } \\
\text { impacted the learning context. }\end{array}$ \\
\hline \multicolumn{5}{|l|}{ Comments: } \\
\hline \begin{tabular}{|l|} 
Areas for \\
Development
\end{tabular} & $\begin{array}{l}\text { No attempt to identify } \\
\text { areas for development. }\end{array}$ & \begin{tabular}{|c|} 
Some attempt to identify \\
areas for development but \\
struggles to articulate their \\
plan to address these areas \\
in the future.
\end{tabular} & $\begin{array}{c}\text { Attempts to identify areas for } \\
\text { development but the plan to } \\
\text { address these areas is unclear } \\
\text { and/or superficial. }\end{array}$ & $\begin{array}{c}\text { Clearly identifies areas for } \\
\text { development; plan is clear and } \\
\text { meaningful. }\end{array}$ \\
\hline \multicolumn{5}{|l|}{ Comments: } \\
\hline \begin{tabular}{|l} 
Reflective \\
Thinking
\end{tabular} & $\begin{array}{l}\text { Does not address one's } \\
\text { own thinking and/or } \\
\text { learning/goals. }\end{array}$ & \begin{tabular}{|c|} 
Attempts to address one's \\
own thinking about \\
learning but is vague \\
and/or unclear about the \\
personal learning \\
process/goals.
\end{tabular} & $\begin{array}{l}\text { Clearly explains one's own } \\
\text { thinking about his/her own } \\
\text { learning processes/goals but } \\
\text { does not include implications } \\
\text { for future learning/goals. }\end{array}$ & $\begin{array}{c}\text { Explains one's own thinking and } \\
\text { learning processes, as well as } \\
\text { implications for future learning/goals. }\end{array}$ \\
\hline \multicolumn{5}{|l|}{ Comments: } \\
\hline Presentation & \begin{tabular}{|c|} 
Written: Document(s) \\
is/are unorganized and \\
unprofessional; \\
documents are submitted \\
late and do not include the \\
appropriate formatting.
\end{tabular} & \begin{tabular}{|} 
Written: Some aspects of \\
the document(s) is/are \\
unorganized or \\
unprofessional; documents \\
are late or do not include \\
the appropriate \\
formatting.
\end{tabular} & $\begin{array}{l}\text { Written: Documents are } \\
\text { organized and professional, } \\
\text { but do not include the } \\
\text { appropriate formatting. }\end{array}$ & $\begin{array}{l}\text { Written: Document(s) is/are organized, } \\
\text { professional and formatted } \\
\text { appropriately. All documents are } \\
\text { submitted on time. }\end{array}$ \\
\hline \multicolumn{5}{|l|}{ Comments: } \\
\hline
\end{tabular}

